\title{
Promoting Quality Teaching: Phase 1 of a Case Study and Research Initiative for Progressing Evidence-Based Educational Innovations
}

\author{
Dominique Parrish \\ University of Wollongong, Australia
}

\begin{abstract}
Internationally there is growing attention to the need for higher education institutions to deliver quality teaching that is dynamic, appropriate and able to produce a skilled workforce that will meet the challenges of the 21st century. This paper reports on a strategic educational development initiative (SEDI) that sought to address this goal. The SEDI was designed to promote the identification and support the advancement of educational practices to improve the quality of teaching and thereby the learning outcomes and employability of students. Further, the SEDI aimed to identify enhancements and innovations that could progress faculty and institutional educational priorities. The SEDI focused on bringing about significant pedagogical change and so juxtaposed with the focus on educational practice was the utilization and promotion of sound change management and improvement principles, effective leadership practices and evaluation mechanisms to enable the identification and promotion of quality teaching and a successful transformation process. The project targeted both professional and resource development as a means of improving educational practice and was underpinned by a distributive leadership approach that embraced emotional intelligence ideologies to ensure sustainable transformation. A participatory action research methodology guided by social-constructivism principles, was implemented in two phases - a development and implementation phase and an evaluation and dissemination phase. There was an imperative for participants to disseminate the outcomes and findings from their projects to promote educational innovations that could improve teaching. The challenges that were encountered and strategies to mitigate these are also presented.
\end{abstract}

\section{Introduction}

The global impetus for quality teaching across institutions is a consequence of the: need to significantly increase student numbers, demands in light of expanding diversity across student cohorts;

rise in institutional accountability and potential for reputational risk; competition for funding that is increasingly performance driven; growing pressure to ensure students are well equipped for future career endeavors'; and intensified government reporting requirements and performance scrutiny[1]; [2]; [3].Many of these factors have prompted higher education bodies to contemplate what quality teaching is, how it can be assessed and thereby enhanced [4]. Additionally, the imperative for institutions to produce a skilled workforce that will meet the challenges of the $21 \mathrm{st}$ century has intensified the importance of institutions developing and delivering quality teaching [1].

The overarching goal of quality teaching is the assurance of students' learning and achievement of desired learning outcomes. Various factors contribute to the attainment of quality teaching including curriculum design, content delivery, pedagogic approaches, student support, responsiveness to stakeholder feedback and effective assessment of learning [3]. Quality teaching is predominantly advanced through two main approaches: top-down where the institution and its leadership determine the focus and direction for quality teaching and bottom-up, where quality teaching transpires from the activities and innovations of academics and has the potential to influence the practices of academics more broadly across the university and external to the institution [1].

Educational priorities identified in both faculty and institutional strategic plans are often prescribed with a goal of promoting quality teaching and addressing identified teaching deficits. To ensure that quality teaching is appropriately advanced, the identification of teaching deficits and articulation of quality teaching educational innovations should be informed by valid and reliable data and not just based on individual or collective anecdotal observations [5]. The initiative reported on in this paper was conceptualized firstly to address areas of need that emerged from data collected across publicly verifiable instruments and other more 
targeted audits and inventories; secondly to meet institutional requirements in relation to quality teaching and strategic educational priorities; and thirdly to enhance student learning and achievement and their capacity to become confident, capable, lifelong learners with the requisite skills to address the challenges of the 21 st century.

\section{Engendering sustainable change and transformative practice in higher education}

Emotionally intelligent leadership has been posited as a crucial requisite for affecting sustainable change and encouraging transformative teaching practice in higher education [3]; [6].Most important, are the emotional intelligence traits of empathy, inspiring and guiding others and responsibly managing oneself [6]; [7]; [8]. Table 1 provides a summary of these traits in the context of change management [6].

Table 1. Specific emotional intelligence traits for higher education change management

\begin{tabular}{|c|c|}
\hline Trait & Contextual Application \\
\hline Empathy & $\begin{array}{l}\text { Actively consulting with those } \\
\text { engaged in the change process and } \\
\text { for whom it affects about how the } \\
\text { change might be employed. } \\
\text { Ensuring that individuals know their } \\
\text { responsibilities in the implementation } \\
\text { of the change process. } \\
\text { Accurately discerning and } \\
\text { accommodating the motivations, } \\
\text { interests, concerns and needs of those } \\
\text { integral to the change. } \\
\text { Aptly utilising the skills of } \\
\text { individuals and developing areas } \\
\text { where deficits exist. } \\
\text { Appropriately managing conflict and } \\
\text { fostering a safe and supportive work } \\
\text { environment. }\end{array}$ \\
\hline $\begin{array}{l}\text { Inspiring } \\
\text { and guiding } \\
\text { others }\end{array}$ & $\begin{array}{l}\text { Regularly communicating, } \\
\text { reinforcing and reiterating the need } \\
\text { for the change. } \\
\text { Compellingly convincing those } \\
\text { involved in and affected by the } \\
\text { change, of the need for the change. } \\
\text { Motivating, directing and assisting } \\
\text { individuals to understand their role in } \\
\text { affecting the change. } \\
\text { Being resilient to challenges and } \\
\text { setbacks } \\
\text { Continually assessing the viability } \\
\text { and implementation of the change }\end{array}$ \\
\hline
\end{tabular}

\begin{tabular}{|c|c|}
\hline Trait & Contextual Application \\
\hline $\begin{array}{c}\text { Responsibly } \\
\text { managing } \\
\text { oneself }\end{array}$ & $\begin{array}{c}\text { Conscientiously managing one's } \\
\text { emotions and behavior to create } \\
\text { positive conditions and relationships } \\
\text { with others. } \\
\text { Being appreciative and responsive to } \\
\text { the impact that one's actions and } \\
\text { temperament can have on others and } \\
\text { the situation. } \\
\text { Being reflective and honestly } \\
\text { assessing and identifying ways in } \\
\text { which one can better manage the } \\
\text { change process }\end{array}$ \\
\hline
\end{tabular}

The other key requisite that has been suggested as critical for affecting sustainable change and encouraging transformative teaching practice is a sound approach to change management [3]. Scott, Coates and Anderson [3], prescribe that, in a higher education context, to be effective the change management approach should use pilot projects as a means of identifying how to make the desired change and ensure that: decisions are evidence-based and data driven; those involved in the change know how the change will affect them; the change is widely, clearly and consistently communicated to key stakeholders; and there is a solid strategy for identifying, recognizing and disseminating good practice. Furthermore, the university culture needs to be prepared and willing for the change [2]. The Carnegie Foundation for the Advancement of Teaching [9] proposes six principles that are highly significant in affording strategic and transformational educational change. These are: Engage end-users and key stakeholders in the change regularly and from the very beginning; confirm that the change is reliably scalable; clearly communicate the reasons for change; Embed evaluative measures to quantify outcomes, assess processes and identify unintended achievements; Adopt an implementation cycle of plan, execute, review and act; and embrace networking opportunities and harness communities of practice.

The initiative reported on in this paper, which sought to affect sustainable change and foster transformative educational practice, encouraged emotionally intelligent leadership, embraced the Carnegie Foundation principles for affecting strategic and transformational educational change and adopted a sound approach to change management. 


\section{Drivers for change and transformation}

This strategic educational development initiative, which was coined the SEDI was conducted in the Faculty of Science, Medicine and Health (SMAH) at the University of Wollongong (UOW), Australia. It was designed to address both faculty and institutional education priorities, which were related to technology-enhanced learning (TEL) and learning oriented assessment (LOA). Additionally, stakeholder feedback that had been gathered over a period of 5 years from subject and course related data, including subject evaluations and course experience surveys were integral in determining the focus of the educational innovations.

The increasing pace of change across the higher education sector and emerging technologies has necessitated the impetus for institutions to identify how technology-based learning can be fruitfully integrated into the delivery of subjects and courses. The UOW rolled out a new Technology-Enriched Learning Strategy in 2014, which subsequently underpinned the focus of the SMAH Strategic Education Plan. A decline in SMAH student numbers particularly in postgraduate studies prompted an audit of other institutions' enrolments in like courses. The findings from this audit illuminated the fact that online courses across the Australian higher education sector had significantly increased in student enrolments. This finding was further motivation for the faculty to explore how online learning could be more profitably and effectively integrated into course offerings and as a consequence include a focus on TEL in both the faculty strategic education plan and the SEDI.

Assessment is a vital responsibility and obligation of higher education providers and those teaching in them. It influences student learning, contributes to career readiness and employability and directs students' attention to knowledge and skills critical to future learning [10]. However, research suggests that current assessment practices in higher education are not adequately equipping students with skills for life-long learning and as a result failing to prepare them for their future directions and careers [10]. Commonly, assessment in higher education focuses on generating a grade and testing existent knowledge, in other words assessment OF learning [10]; [11]. Learning-oriented assessment (LOA) is a term describing assessment that is concerned with assessment FOR learning [11]. This approach to assessment focuses on the enhancement of student learning through the engagement and completion of assessment tasks. LOA is built around a tripartite approach to assessment in which the assessment tasks are designed as learning tasks that facilitate deeper learning experiences; stimulate active consideration of assessment criteria and standards; and result in advanced achievement of learning outcomes. LOA tasks have real world relevance and engage students for a period of time rather than just short bursts of effort that are commonly invested when completing assignments or examinations. Sound LOA tasks regularly and actively engage students with the high-quality assessment criteria they will be assessed against and encourage peer and self-evaluation and feedback. Finally, detailed formative and summative feedback as 'feed-forward' is provided to students to support their future work and learning [11]. Table 2 provides an overview of the elements of quality teaching that are pertinent in each of LOA and TEL.

Table 2. Overview of SEDI quality teaching elements

\begin{tabular}{|c|c|}
\hline $\begin{array}{c}\text { Learning Oriented } \\
\text { Assessment (LOA) }\end{array}$ & $\begin{array}{c}\text { Technology-Enhanced } \\
\text { Learning (TEL) }\end{array}$ \\
\hline $\begin{array}{c}\text { Designing assessment } \\
\text { tasks as learning tasks }\end{array}$ & $\begin{array}{c}\text { Identifying strategies to } \\
\text { facilitate a flipped } \\
\text { classroom model }\end{array}$ \\
\hline $\begin{array}{c}\text { Facilitating students' } \\
\text { active consideration of } \\
\text { assessment task criteria }\end{array}$ & $\begin{array}{c}\text { Designing innovations in } \\
\text { utilizing learning spaces }\end{array}$ \\
\hline $\begin{array}{c}\text { Designing assessment } \\
\text { tasks that have real } \\
\text { world relevance }\end{array}$ & $\begin{array}{c}\text { Integrating mobile } \\
\text { technologies to connect } \\
\text { the curriculum with real } \\
\text { life issues }\end{array}$ \\
\hline $\begin{array}{c}\text { Engaging students in } \\
\text { assessment tasks for a } \\
\text { period of time rather } \\
\text { than just short bursts of } \\
\text { effort }\end{array}$ & $\begin{array}{c}\text { Pedagogically } \\
\text { appropriate } \\
\text { incorporation of LMS } \\
\text { (e.g. Moodle) tools into } \\
\text { learning }\end{array}$ \\
\hline $\begin{array}{c}\text { Encouraging and } \\
\text { facilitating peer and self- } \\
\text { evaluation }\end{array}$ & $\begin{array}{c}\text { Utilizing electronic } \\
\text { communication in } \\
\text { learning (e.g. blogs, open } \\
\text { textbooks, wikis) }\end{array}$ \\
\hline $\begin{array}{c}\text { Providing feedback as } \\
\text { feed forward to support } \\
\text { future learning }\end{array}$ & \\
\hline
\end{tabular}

Learning analytics collated by SMAH, consistently suggested that students were dissatisfied with the assessment tasks they were completing and the quality of assessment feedback that they were receiving. An audit of assessment tasks in all subjects offered by the Faculty also highlighted an alarmingly high percentage of assessment tasks that were being undertaken in the Faculty were quizzes, tests or exams, which by nature, has a focus on assessment OF learning rather than assessment FOR learning. 
Preliminary consultation conducted with academics, about integrating LOA practices in their courses and subjects, revealed significant resistance to this educational innovation and highlighted their concerns that adopting a learning-oriented approach to assessment would substantially increase workload. Further, some academics voiced skepticism about the value of undertaking such a labor-intensive approach to assessment and questioned whether it would have a significant enough impact on student outcomes and experience to warrant the investment.

These collective findings identified the need for a renewal of assessment practices across the Faculty and compelled the inclusion of a focus on LOA in both the SMAH strategic education plan and the SEDI.

\section{The Strategic Educational Development Initiative (SEDI)}

The overarching goal of SEDI was to support the advancement of educational practices, improve the quality of teaching and as a consequence of these enhancements, deepen the learning outcomes and employability of students. An immediate outcome of this initiative was to establish a suite of quality teaching principles, practices and exemplars that could be shared, re-used and repurposed by academics from across the Faculty and more broadly. Identifying and communicating the value and need, of implementing pedagogically sound quality teaching and the impact of this was also a desired outcome of the initiative. A longer-term outcome was to significantly transform Faculty teaching practices particularly with regard to both assessment and feedback and technology-enhanced learning. With these strategic outcomes in mind, the rationalized objectives of the SEDI were to: 1) Establish a network of appropriately skilled academic change agents who could mentor and support the cascading and integration of educational change and transformative teaching practice across subjects and courses offered by the Faculty; 2) Utilize action learning projects as a means of progressing transformative educational practice and identifying how to facilitate sustainable change in subjects and courses across the Faculty; and 3) Embed mechanisms to evaluate and report on innovations, outcomes, progress and impact of the implemented initiative.

Participatory action research (PAR), which has played a fundamental role in progressing educational change and developing teachers and teaching [12]; [13], underpinned and informed the implementation of the SEDI. The MERI (Monitoring, Evaluation, Research and Improvement) evaluation approach
[14] was also employed with an emphasis on "action that is evaluated and researched with a view to identifying both where it has 'worked' and what to do if it can be improved by those who are parties to that action" [14, p.16]. The PAR methodology and MERI evaluation approach were guided by socialconstructivist thinking whereby knowledge and skills are advanced within a supportive community of practice (COP) [15]; [16].

The implementation plan for the SEDI (summarized in Table 3) included two phases: the development and implementation phase which comprised iterative cycles of testing and refinement of educational strategies, and the evaluation and dissemination phase, which incorporated the rationalization of an evidence-based plan for cascading the educational innovations and transformative teaching practice across the faculty, institution and wider sector.

Table 3. SEDI project implementation phases and activities

\begin{tabular}{|c|c|}
\hline $\begin{array}{c}\text { PHASE 1: Development \& } \\
\text { Implementation } \\
\text { (Sept 2015 - Feb 2016) }\end{array}$ & $\begin{array}{c}\text { PHASE 2: Evaluation \& } \\
\text { Dissemination } \\
(\text { Mar - Dec 2016) } \\
\end{array}$ \\
\hline $\begin{array}{l}\text { Recruit project teams } \\
\text { Assign a Scholar to the } \\
\text { project team to act as a } \\
\text { mentor and support }\end{array}$ & Analyze collected data \\
\hline $\begin{array}{l}\text { Project teams develop } \\
\text { action learning projects to } \\
\text { foster an educational } \\
\text { innovation for their } \\
\text { subject/course }\end{array}$ & $\begin{array}{l}\text { Project teams develop and } \\
\text { publish an overview of their } \\
\text { educational innovations on } \\
\text { the Faculty website }\end{array}$ \\
\hline $\begin{array}{l}\text { Project teams meet } \\
\text { regularly with engage in } \\
\text { COP with other project } \\
\text { teams to discuss and } \\
\text { progress their action } \\
\text { learning projects and } \\
\text { educational innovations and } \\
\text { to participate in targeted PD } \\
\text { workshops } \\
\end{array}$ & $\begin{array}{l}\text { Project teams deliver } \\
\text { presentations about their } \\
\text { educational innovations at } \\
\text { Faculty workshops \& } \\
\text { teaching \& learning forums. }\end{array}$ \\
\hline $\begin{array}{l}\text { Project teams implement } \\
\text { action learning projects and } \\
\text { educational innovations }\end{array}$ & $\begin{array}{l}\text { A report on the outcomes } \\
\text { and research findings of the } \\
\text { action project is developed } \\
\text { and made available on the } \\
\text { Faculty website. }\end{array}$ \\
\hline \multirow[t]{2}{*}{$\begin{array}{l}\text { Evaluative and research } \\
\text { data is collected as per the } \\
\text { evaluation plan }\end{array}$} & $\begin{array}{l}\text { Project teams disseminate } \\
\text { an aspect(s) of their } \\
\text { educational innovations at a } \\
\text { conference, in a journal } \\
\text { article or book chapter. }\end{array}$ \\
\hline & $\begin{array}{c}\text { A plan to facilitate and } \\
\text { support the cascading of } \\
\text { educational practices in } \\
\text { subjects and courses across }\end{array}$ \\
\hline
\end{tabular}




\begin{tabular}{|c|c|}
\hline $\begin{array}{c}\text { PHASE 1: Development \& } \\
\text { Implementation } \\
\text { (Sept 2015 - Feb 2016) }\end{array}$ & $\begin{array}{c}\text { PHASE 2: Evaluation \& } \\
\text { Dissemination } \\
\text { (Mar - Dec 2016) }\end{array}$ \\
\hline \multirow{1}{*}{ the Faculty is developed } \\
\cline { 2 - 2 } & $\begin{array}{c}\text { A Focus group(s) is } \\
\text { conducted to validate/ } \\
\text { refine the developed } \\
\text { Faculty plan to cascade the } \\
\text { SEDI and educational } \\
\text { innovation. }\end{array}$ \\
\hline
\end{tabular}

Phase 1, the development and implementation phase, initially involved the recruitment of project teams to develop and implement action-learning projects focused on progressing an aspect of LOA and/or TEL, which would be authentically implemented in their subject/course. Over a sixmonth period, these project teams designed the LOA and TEL action projects and the associated implementation and evaluation plans, which would be executed in the first standard academic session of 2016.Additionally, teams identified the resources and support that would be needed to implement their projects. Each project team was assigned a SMAH Learning and Teaching Scholar (Scholar) as a mentor. Scholars were an already established community of faculty leaders in learning and teaching with responsibility for collectively working toward advancing learning and teaching in the Faculty. The Scholars worked with their assigned project teams to encourage and develop competence in emotionally intelligent leadership practices and change management principles and processes. The project teams were provided with specific and targeted professional development throughout the initial six-month period, to build their capacity to design, implement and evaluate their action learning projects. Project teams collectively also met regularly with the other project teams to share their implementation progress, discuss challenges they were experiencing, identify solutions to these challenges and explore opportunities for progressing their projects and outcomes more broadly across the Faculty.

Phase 2, the evaluation and dissemination phase (to be implemented March- December 2016, prior to this paper), will involve the analysis of collected data and the development of collateral to disseminate and showcase outcomes and recommendations from the implemented action learning projects. Data analysis will include assessment, evaluation and reporting on: stakeholder satisfaction, student achievement and outcomes, and the implemented action learning process. Qualitative data will inform the ensuing: generation of recommendations for subsequent iterations of the SEDI; development of a plan to cascade the initiative more broadly across the
Faculty; and advancement of educational innovations in subjects and courses. Project teams will also be expected to develop collateral that could be showcased in conference presentations, journal articles, book chapters, websites and professional development workshops.

Across both phases of the SEDI, project teams are required to submit progress reports providing details of the status and developments of their projects' implementation. A focus group will be conducted with the project team participants, at the conclusion of the initiative, to validate and further refine a preliminary conceptualized plan to facilitate and support cascading of the SEDI broadly across the Faculty.

\subsection{SEDI phase 1 implementation}

A call for project teams interested in being involved in the inaugural SEDI was sent to all academics in the SMAH faculty, via email, at the end of July 2015. This call included details of the SEDI and invited those interested to an information session a week later. Expressions of interest (EOI) were invited, again by email, from academics and teaching teams following the facilitation of the information session. A total of thirteen EOIs were received from across the faculty and these were judged by a panel of Scholars who were available at the time of the EOI assessment. The EOI questions and criteria used to assess the EOIs are detailed in Table 4.

Table 4. Overview of SEDI EOI questions and assessment criteria

\begin{tabular}{|c|c|}
\hline Questions & Assessment Criteria \\
\hline $\begin{array}{c}\text { Provide details of the } \\
\text { strategic priority area your } \\
\text { project will explore }\end{array}$ & $\begin{array}{c}\text { An area of strategic priority } \\
\text { for the faculty/university in } \\
\text { relation to LOA and/or TEL } \\
\text { is being addressed }\end{array}$ \\
\cline { 2 - 2 } & $\begin{array}{c}\text { Addresses other } \\
\text { institutional strategic } \\
\text { educational priorities(other } \\
\text { than LOA or TEL) }\end{array}$ \\
\hline $\begin{array}{c}\text { What quality teaching } \\
\text { element(s) (the list in Table } \\
2 \text { was provided) and } \\
\text { educational innovation(s) } \\
\text { will your project address }\end{array}$ & $\begin{array}{c}\text { The quality teaching } \\
\text { element(s) and/or } \\
\text { educational innovations } \\
\text { have applicability to other } \\
\text { faculties/Schools/ } \\
\text { disciplines/subjects }\end{array}$ \\
\hline $\begin{array}{c}\text { Provide details of how your } \\
\text { project will investigate the } \\
\text { nominated quality teaching } \\
\text { element(s) and progress } \\
\text { teaching/educational } \\
\text { practice }\end{array}$ & $\begin{array}{c}\text { How the quality teaching } \\
\text { element will be investigated } \\
\text { is clear and appropriate }\end{array}$ \\
\cline { 2 - 2 } & $\begin{array}{c}\text { The proposed project can } \\
\text { be implemented as an } \\
\text { action learning project }\end{array}$ \\
\cline { 2 - 2 } & $\begin{array}{c}\text { The proposed project has } \\
\text { scalability }\end{array}$ \\
\hline
\end{tabular}




\begin{tabular}{|c|c|}
\hline Questions & Assessment Criteria \\
\hline & $\begin{array}{c}\text { The proposed project the } \\
\text { potential to lead to future } \\
\text { funding opportunities } \\
\text { external to the university }\end{array}$ \\
\hline $\begin{array}{c}\text { What are the } \\
\text { demographics of the } \\
\text { class/course that your } \\
\text { educational innovation } \\
\text { will be implemented in? }\end{array}$ & $\begin{array}{c}\text { The proposed project will } \\
\text { be implemented with a } \\
\text { student cohort that will } \\
\text { avail robust data to be } \\
\text { collected (i.e. large class, } \\
\text { delivered over a range of } \\
\text { cohorts) }\end{array}$ \\
\hline
\end{tabular}

Nine of the thirteen EOIs received were successful. These projects drew from five of the six Schools in the Faculty. Each successful project team was assigned a Scholar from outside their School and discipline. The project teams and Scholars met during August and September 2015 to develop and finalize their action learning project implementation and evaluation plans, this included identifying: the specific innovation the project would be addressing; how the educational innovation would be evaluated; the research question(s) the project would be investigating; the research data that would be collected; the relevance of the educational innovation to other disciplines/areas of learning and the support that would be required to implement the action learning plan. All of the project teams came together, for a meeting in October 2015, to share the details of their implementation plans with the other project teams and Scholars. Each project team submitted a progress report in December 2015 and again met to share their projects' implementation progress, discuss challenges that they were experiencing and possible solutions to these challenges.

\section{Lessons learned, challenges and insights}

An important lesson that has transpired from the implementation of phase one is the need to ensure that expectations and conditions of engagement are acutely understood and clearly and regularly communicated. From the initial information session participants in the SEDI have been aware of the expectations and deliverables that are requirements of their involvement in the program. There is an expectation that SEDI participants will act as mentors in subsequent SEDI iterations and will potentially become Scholars themselves, which is seen as an esteemed appointment. Project teams also knew that any learning or educational resources developed as a consequence of or for their actionlearning project, must be shared and made available via a central Faculty learning and teaching repository. Finally there is an expectation that there will be at least three formal dissemination outputs including a presentation at a Faculty showcase on learning and teaching and the provision of regular progress reports and status updates for the faculty website. Project teams may then select whether they disseminate on their project outcomes via a conference presentation(s) or journal article(s) or book chapter(s).

Initiatives such as the SEDI require a commitment from academics that is above and beyond their normal workload. As such, it was important to rationalize and communicate the benefits, opportunities and incentives that would be afforded to those who participated in the SEDI. Career progression and advancement is a major motivating enticement for academics and at the initial information session and subsequent meetings since, SEDI participants have been informed of how their responsibilities in the SEDI aligns to the university's Academic Performance Framework and as such could benefit their promotion aspirations. This has been well received by participants and clearly an effective incentive. Additionally, given the implications of the SEDI on participants' workload a requirement of the application process was that the participants' supervisor signed off on and agreed to support their involvement in the initiative.

The other salient motivator for academics investing in initiatives such as the SEDI is funding support. There are two aspects to acquiring funding support, firstly the procurement of funding and secondly the provision of funding to beneficiaries. The procurement of funding can be challenging especially given the current economic climate in higher education institutions. It is imperative that the benefits for a faculty or other funding provider is rationalized and clearly and convincingly communicated to assist the acquisition of funding. The outcomes of the SEDI were clear benefits to the faculty, including: a network of change agents who could advance educational innovations and promote quality teaching broadly across the faculty; exemplars of good practice that could be showcased and proactively promoted within and external to the faculty/university; and scholarship and scholarly outputs that contribute to the learning and teaching and research yields of the faculty. In this iteration of the SEDI a modest allocation of funding was made available so the next challenge was how to get economies of scale from the available funding allocation. Instead of distributing sums of money to the individual projects the funding allocation was maintained in a central cost centre and project teams submitted firstly funding requests providing details of the financial support they required then once approved invoices that were paid from the central 
cost centre. Most of the projects requested research assistant support and conference funding assistance. A central research assistant was employed on a casual basis for 2 days a week and assigned to the projects on a needs basis. Conference funding was capped at $\$ 500$ per project team.

The SEDI was introduced in July 2015 and needed to be implemented from March 2016; these rigid timeframes were a challenge, further complicated by the fact that there were some explicit deliverables required across the initial six-month period, which if they weren't met could have significant impact on the sustainability and success of the SWEDI. To combat this challenge Scholars were charged with the responsibility of closely monitoring the progress of the project they had been assigned and ensuring that they engaged in regular meetings with the project teams to safeguard that deliverables and deadlines were being met. Ongoing funding payments were only honored if negotiated deliverables (e.g. progress reports, implementation and evaluation plans) were provided.

There has been a contagious enthusiasm that has resulted from participants' engagement in the SEDI and enquiries about subsequent iterations of the initiative from academics not currently involved in the SEDI have been increasing. There has also been discussion at faculty executive and senior institutional levels about the SEDI, which has inspired other faculties to consider adopting a similar approach to identify and advance quality teaching and educational innovation. This interest has been beneficial to engendering future Faculty funding and thereby enabling subsequent iterations of the SEDI to transpire.

\section{Conclusion}

The expected outcomes of this educational initiative (SEDI) include a network of academic change agents who could mentor and support peers to integrate educational innovations and quality teaching across subjects and courses offered by the Faculty. Further, a suite of well-developed resources for integrating LOA and TEL into university subjects and courses would be made available via relevant learning and teaching networks and for a. The rationalization of an evidence-based strategy for affecting sustainable change and encouraging transformative teaching practice across the Faculty and institution in the short term and potentially the higher education sector both nationally and internationally in the long-term is also an anticipated outcome. A quantum of scholarship would be amassed through presentations and publications. These scholarly research outputs could advance assessment thinking and practice as well as strengthen the teaching - research nexus, which should be a key responsibility of all universities [17]. Finally, this research study would seek to develop resources that could showcase good practice, support future innovators and inform transformative initiatives. The resources developed could be made publicly available for use, re-use, repurposing and further sharing across the sector locally, nationally and internationally.

\section{References}

[1] Hénard, F., (2009). 'Learning our lesson: Review of quality teaching in higher education', Institutional Management in Higher Education, OECD; http://www.oecd.org/edu/imhe/44058352.pdf (Access date: 12 January 2016).

[2] Hénard, F. and Roseveare D., (2012). 'Fostering quality teaching in higher education: Policies and practices', Institutional Management in Higher Education, OECD; http://www.oecd.org/edu/imhe/

QT\%20policies\%20and\%20practices.pdf (Access date: 12 January 2016).

[3] Scott, G., Coates, H. and Anderson, M., (2008). 'Learning leaders in times of change: Academic leadership capabilities for Australian higher education', university of Western Sydney and Australian Council for Educational Research;http://research.acer.edu.au/cgi/viewcontent.cgi?a rticle $=1001 \&$ context=higher_education (Access date: 12 January 2016).

[4] Chalmers, D., (2007). 'A review of Australian and international quality systems and indicators of learning and teaching';http://citeseerx.ist.psu.edu/viewdoc/download? doi=10.1.1.169.3919\&rep=rep1\&type=pdf $\quad(13 \quad$ January 2016).

[5] Coates, H., (2010). 'Defining and monitoring academic standards in Australian higher education', HigherEducation Management and Policy 22(1), pp. 1-17.

[6] Parrish, D., (2015). 'The relevance of emotional intelligence for leadership in a higher education context', Studies in Higher Education 40(5), pp. 821-837.

[7] Bryman, A., (2009). 'Effective leadership in higher education: Final report', Research and Development Series, Leadership Foundation for Higher Education; http://www.lfhe.ac.uk/en/test-

section/publication.cfm/S1\%20-\%2012 (Access date: 14 January 2016).

[8] Ying, C. Y. and Ting, S.K.T., (2010). 'The relationship between emotional intelligence and effective leadership among academic heads in higher learning educational institutions', in proceedings of the International Conference on Business and Economic Research (ICBER 2010): Sarawak, Malaysia 
[9] Carnegie Foundation for the Advancement of Teaching, 'The Six Core Principles of Improvement', http://www.carnegiefoundation.org/our-ideas/six-coreprinciples-improvement/ (Access date: 14 January 2016)

[10] Boud, D. and Falchikov, N., (2007). Rethinking assessment in higher education, Routledge, New York.

[11] Carless, D., (2007). 'Learning-oriented assessment: Conceptual bases and practical implications', Innovations in Education and Teaching International 44 (1, pp. 57-66).

[12] Carr, W. and Kemmis, S., (1986). Becoming critical: Education, knowledge and action research, The Falmer Press, London.

[13] Eliot, J., (1991). Action research for education change, Open University Press, Philadelphia.

[14] Wadsworth, Y., (2011). Do it yourself social research, 3rd Edition, Allen \& Unwin, Crows Nest.

[15] Vygotsky, L. S., (1978). Mind in society: the development of higher psychological processes, Harvard University Press, Cambridge.

[16] Wenger, E. McDermott, R. and Snyder, W., (2002). Cultivating communities of practice: A guide to managing knowledge, Harvard Business School Press, Boston.

[17] Boyer, E., (1990). Scholarship Reconsidered: Priorities for the Professoriate, Carnegie Foundation for the Advancement of Teaching. University of Princeton, New Jersey. 